\title{
СТРОЕНИЕ ЗЕМНОЙ КОРЫ ПОЛЯРНОГО СЕКТОРА УРАЛЬСКОЙ СКЛАДЧАТОЙ СИСТЕМЫ ПО ДАННЫМ ГСЗ
}

\author{
В.С. Дружинин, В.А. Ракитов*, В.Ю. Осипов, Н.И. Начапкин, В.В. Недядько* \\ Институт геофизики им. Ю.П. Булашевича УрО РАН, 620016, Екатеринбург, ул. Амундсена, 100, Россия \\ * ОП Центр «Геон» ГФУП «ВНИИГеофизика», 107140, Москва, ул. Нижняя Красносельская, 4, Россия
}

\begin{abstract}
На основании сейсмической информации по профилю Полярно-Уральский трансект и результатов выполненных тематических исследований составлен сводный разрез земной коры Уральской складчатой системы длиной 450 км в районе $67^{\circ}$ с.ш. и 60-69 в.д. Основные элементы глубинного строения, установленные на более южных широтах, сохраняются для данного сечения. При этом единая глубинная структура разделяется на западную и восточную ветви. Западная - имеет северо-западное направление и соответствует Западно-Уральской мегазоне. В состав восточной ветви, которая имеет северо-восточное направление, входят Центрально-Уральская и Восточно-Уральская мегазоны.
\end{abstract}

Земная кора, глубинное строение, глубинное сейсмическое зондирование, Уральская складчатая система

\section{CRUSTAL STRUCTURE IN THE POLAR SECTOR OF THE URALS FOLDED SYSTEM (from DSS data)}

\section{V.S. Druzhinin, V.A. Rakitov, V.Yu. Osipov, N.I. Nachapkin, and V.V. Nedyad'ko}

A $450 \mathrm{~km}$ long composite crustal section of the Urals folded system at $67^{\circ} \mathrm{N}$ and $60-90^{\circ} \mathrm{E}$ has been compiled from seismic data on the Polar Urals transect and the results of targeted studies. The main elements of the subsurface structure at more southerly latitudes are preserved for this cross section. The general deep-seated structure is divided into the western and eastern branches. The western one has a northwestern trend and corresponds to the West Urals megazone. The eastern one, with a northeastern trend, includes the Central Urals and East Urals megazones.

Earth's crust, deep-level structure, deep seismic sounding, Urals folded system

\section{ВВЕДЕНИЕ}

Строение земной коры Полярного сектора Уральской складчатой системы (УСС) вызывает особый интерес в связи со сложным характером взаиморасположения геологических структур первого порядка Тимано-Печорского геоблока, Пайхойского мегаблока Уральской складчатой системы и Западно-Сибирского геоблока (рис. 1). Аналогичная сложная картина наметилась по специфике строения верхней части литосферы [Дружинин и др., 2009, 2012]. Но слабым звеном этих исследований является отсутствие конкретной сейсмической информации о строении земной коры по уральской части рассматриваемой территории. В начале XXI в. был пройден Полярно-Уральский трансект протяженностью около 270 км с использованием комбинированной системы наблюдений: ГСЗ, МОВЗ и глубинное ОГТ. В работах приняли участие ОАО «Баженовская геофизическая экспедиция» и ОП Центр «Геон» ГФУП «ВНИИГеофизика». Поэтому появилась возможность с учетом ранее выполненных глубинных исследований по восточным частям геотраверсов Глобус (Купянск-Воркута), Агат-2 и результатов тематических работ [Дружинин и др., 2012, 2013] получить более достоверную картину глубинного строения. В данной статье на основе сводного сейсмогеологического разреза рассмотрены особенности строения земной коры Полярного сектора Уральской складчатой системы.

\section{МЕТОДИКА ТЕМАТИЧЕСКИХ ИССЛЕДОВАНИЙ}

C применением методики глубинного геокартирования [Дружинин и др., 2013] в процессе суммирования данных ГСЗ по Тимано-Печорской плите (ТПП) составлены сейсмогеологические разрезы земной коры, представленные на рис. 2 [Дружинин и др., 2011]. Методика была разработана в ИГФ УрО РАН (г. Екатеринбург) по материалам анализа, обобщения и геологической интерпретации значительных объемов комплексной глубинной сейсмической информации, а также данных по сверхглубокому и глубокому бурению, вскрывших породы от нижнего архея до кайнозоя включительно. Промежуточные ре- 
Рис. 1. Выкопировка из [Тектоническая карта..., 1979].

1 - разломы; 2 - Главный Уральский разлом; 3 - контуры открытого Урала; 4 - осадочные отложения Тимано-Печорской плиты; 5 - осадочные отложения Предуральского прогиба и складчатые комплексы Западного Урала; 6 - вулканогенные и интрузивные комплексы Центрально-Уральского поднятия и Тагильского прогиба; 7 - осадочные отложения Западно-Сибирской геосинеклизы; 8 - интрузивные комплексы основного и ультраосновного составов $(a)$, гранитоидные комплексы (б); 9 - профили ГСЗ: Агат-2 (1), КупянскВоркута (2), Полярно-Уральский трансект ГС3, МОВ3 (3), положение сводного разреза по полярной части Уральской складчатой системы (4); 10 - Полярно-Уральский трансект ОГТ, ОАО «Баженовская геофизическая экспедиция».

зультаты обобщения данных ГСЗ изложены в ряде монографий, основных отечественных журналах и зарубежных изданиях [Дружинин и др., 1990; Ryzhiy et al., 1992; Druzhinin et al., 1997].

Основой сейсмогеокартирования земной

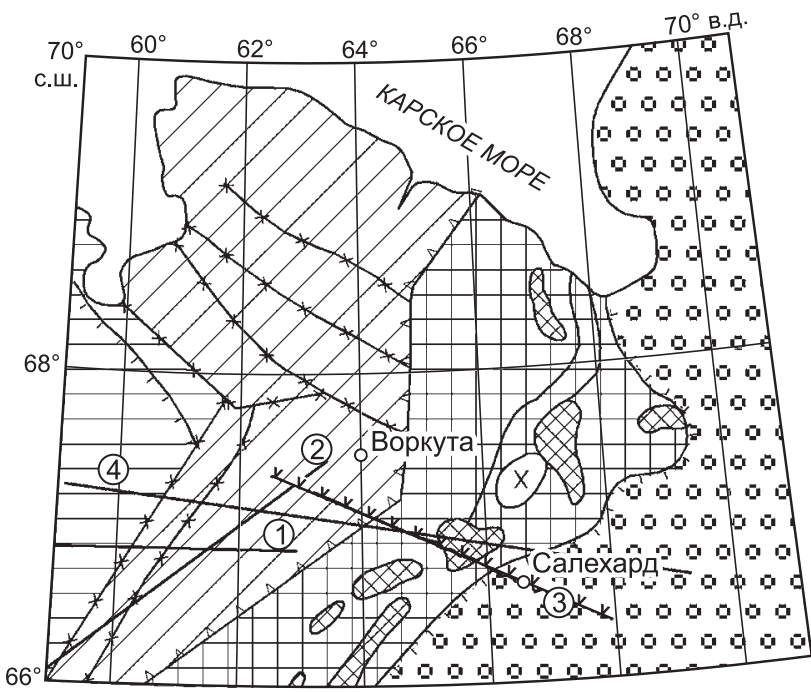
$66^{\circ}$

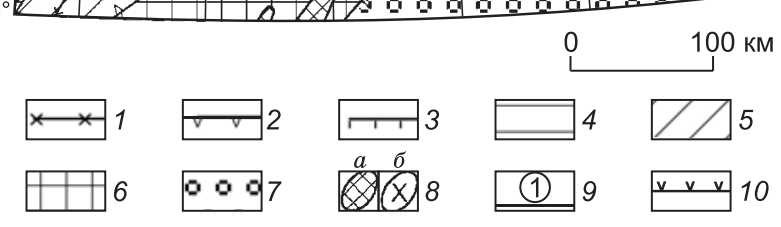
коры является разломно-слоисто-блоковая как наиболее адекватная модель континентальной коры и разделение ее на сейсмогеологические этажи (СГЭ) региональными разделами. Это поверхность нижнеархейского кристаллического фундамента $\left(\mathrm{K}_{01}\right)$, представленного преимущественно серыми гнейсами с выдержанными физическими параметрами $v_{P}=6.1 \pm 0.2 \mathrm{\kappa м} / \mathrm{c}, \rho=2.79 \pm 0.02$ г $\mathrm{cm}^{3}$; поверхность относительно слабоизмененных комплексов верхней мантии $\left(\mathrm{M}_{\text {сг }}\right.$ - сейсмологический раздел между земной корой и верхней мантией) с $v_{P}=8.15 \pm 0.25$ км/c, $\rho=3.32 \pm 0.04$ г $\mathrm{cm}^{3}$. Кристаллическая кора, заключенная между этими поверхностями, подразделяется на две части. Нижняя кора (поверхность раздела $\mathrm{K}_{2}$ ) не тождественна общепринятому понятию сейсмический базальтовый слой. Она характеризуется существенными вариациями значений сейсмических параметров - мощностью от 10-15 до 40 км, скоростью $v_{P}$ от 6.4 до $7.1 \mathrm{kм} / \mathrm{c}$ и, соответственно, изменением расчетной плотности. В подошве протокоры находится промежуточный мегакомплекс (К-М), он особенно значительный по мощности (до 15-20 км) и сложности строения в пограничных структурах, типа Уральской складчатой системы, расположенных между геоблоками (кратонами). Привязка символов сейсмогеологических разделов к общепринятым на сейсмических разрезах следующая: поверхность $\mathrm{K}_{01}$ соответствует осредненному положению границы Форша, $\mathrm{M}_{\mathrm{cr}}-\mathrm{M}$ в пределах стабильных блоков; при наличии переходного мегакомплекса - его подошве. Из-за различий в понятиях сейсмический базальтовый слой и нижняя кора символ $\mathrm{K}_{2}$ целесообразно отнести к поверхности третьего сейсмогеологического этажа. Продолжение в будущем сверхглубокого бурения на древнейших поднятиях континентальной коры, к примеру на Южно-Татарском своде до глубины 8-10 км, даст конкретную информацию по данному вопросу.

Достаточно плотная система наблюдений в методе ГСЗ и применение современных цифровых регистраторов Дельта с трехкомпонентной записью позволили построить детальный сейсмический разрез, определить значения скорости продольных и поперечных волн. Разрез согласован с результатами моделирования для субгоризонтальных слоистых сред.

Важным элементом разломно-слоисто-блоковой модели являются глубинные разломы земной коры, обладающие аномальными чертами строения по сравнению с соседними блоками. В волновой картине им соответствуют дифрагированно-отраженные, вторичные рассеянные волны от локальных резких неоднородностей; изменение амплитудно-частотных характеристик опорных сейсмических горизонтов, которые отчетливо проявляются при непрерывных наблюдениях по системе ГСЗ, МПВ, МОВ, как это было на Свердловском профиле [Дружинин и др., 1976], и по данным глубинного ОГТ на международном геотраверсе Урсейс [Глубинное строение..., 2001].

Объединение совокупности аномальных объектов на сейсмическом разрезе дает представление о положении зоны разломов, ее глубинности и горизонтальных размерах. Для уменьшения степени неоднозначности учитывается второй признак глубинного разлома как пограничной структуры между блоками кристаллической коры. При постановке работ ГСЗ и использовании систем точечного или дискретного профилирования этот признак становится определяющим, хоть и недостаточным для выделения и картирования зоны глубинного разлома. 


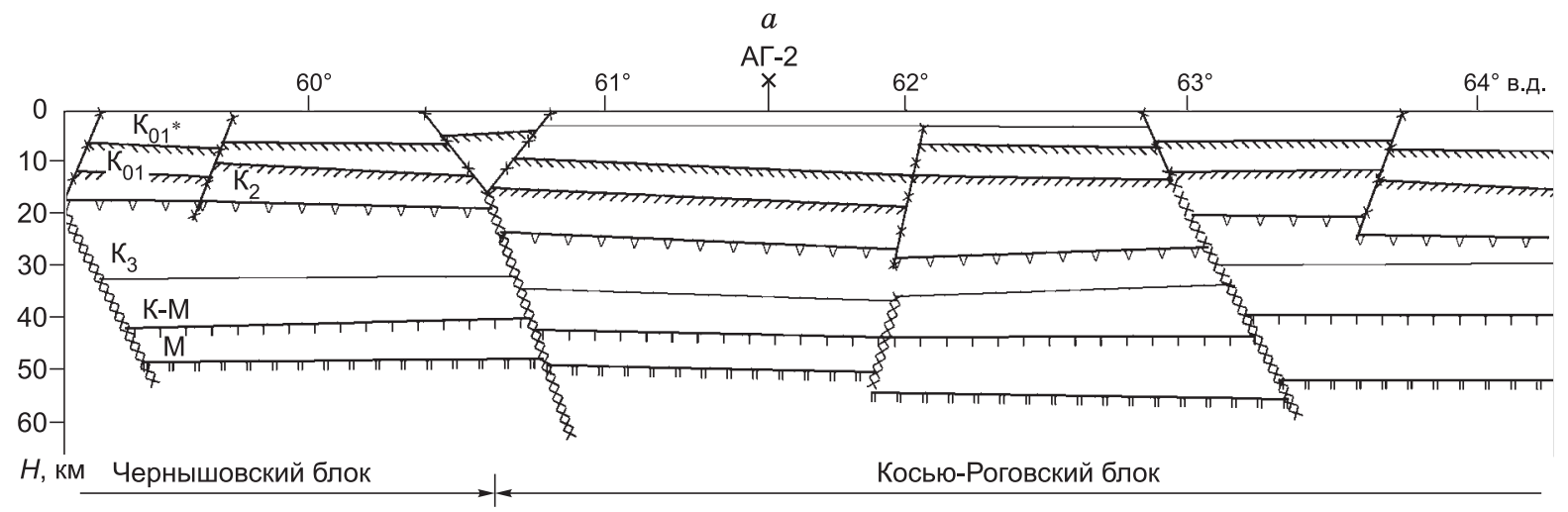

б

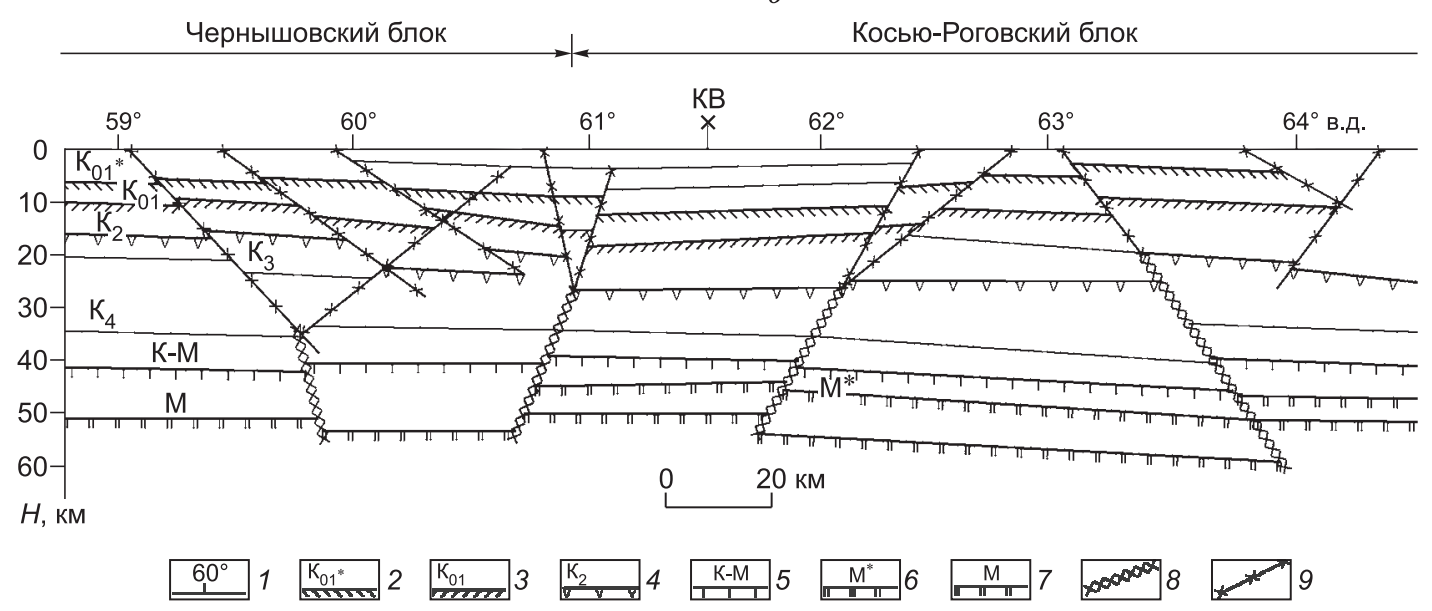

Рис. 2. Сейсмогеологические разрезы по восточному окончанию геотраверса Купянск-Воркута (a), по восточному окончанию геотраверса Агат-2 (б).

1 - линия профиля с градусной привязкой; 2 - поверхность нижнего мегакомплекса первого СГЭ; 3 - поверхность комплексов древнего кристаллического фундамента второго СГЭ; 4 - поверхность комплексов нижней коры, так называемый базальтовый слой; 5 - поверхность в пределах переходного мегакомплекса в низах коры; 6 - граница в пределах переходного мегакомплекса; 7 - поверхность основного сейсмогеологического раздела Мохо между породами земной коры и относительно слабоизмененными породами верхней мантии (перидотит); без индекса приведены промежуточные границы: 8 - основные зоны глубинных разломов; 9 - глубинные разломы и разломы в земной коре. Индексы $\mathrm{K}_{3}, \mathrm{~K}_{4}$ соответствуют промежуточным границам в земной коре. При составлении сейсмогеологических разрезов использовались сейсмические разрезы Центра «Геон» [Егоркин и др., 1991].

Наличие относительно крутопадающих разломов в верхней коре от архея до мезозоя включительно установлено результатами бурения сверхглубоких скважин, т.е. их присутствие до глубин 15 км можно считать доказанным фактом. Следует отметить, что скважинами сверхглубокого и глубокого бурения не удалось подсечь листрические разломы, которым отводится приоритетная роль в плит-тектонике. Примером являются сверхглубокие скважины: Германская КТБ, Уральская, СГ-4, Кулгунинская глубокая скважина на Южном Урале.

К этому следует добавить, что выделение пологопадающих листрических разломов в глубоких частях коры при наличии дискретной, иногда слабой по интенсивности записи волн на временных разрезах стандартного ОГТ неоднозначно.

Основное содержание авторского разреза ГСЗ по Полярно-Уральскому трансекту сохранено (рис. 3), внесены изменения в символы границ, тождественные принятым в Уральском регионе; показаны глубинные разломы с учетом намеченных контактов по скоростным параметрам и морфологическим особенностям блоков земной коры. Также приведена информация по скоростным параметрам, полученным по результатам многоволнового глубинного зондирования, с использованием более плотных систем профилирования с расстоянием между регистраторами $2-3$ км и пунктами взрывов $50-100$ км. Этим обстоятельством объясняется разная насыщенность разрезов по трансекту относительно ранее отработанных геотраверсов. На рис. 3 приведен временной разрез по методу обменных волн удаленных земле- 


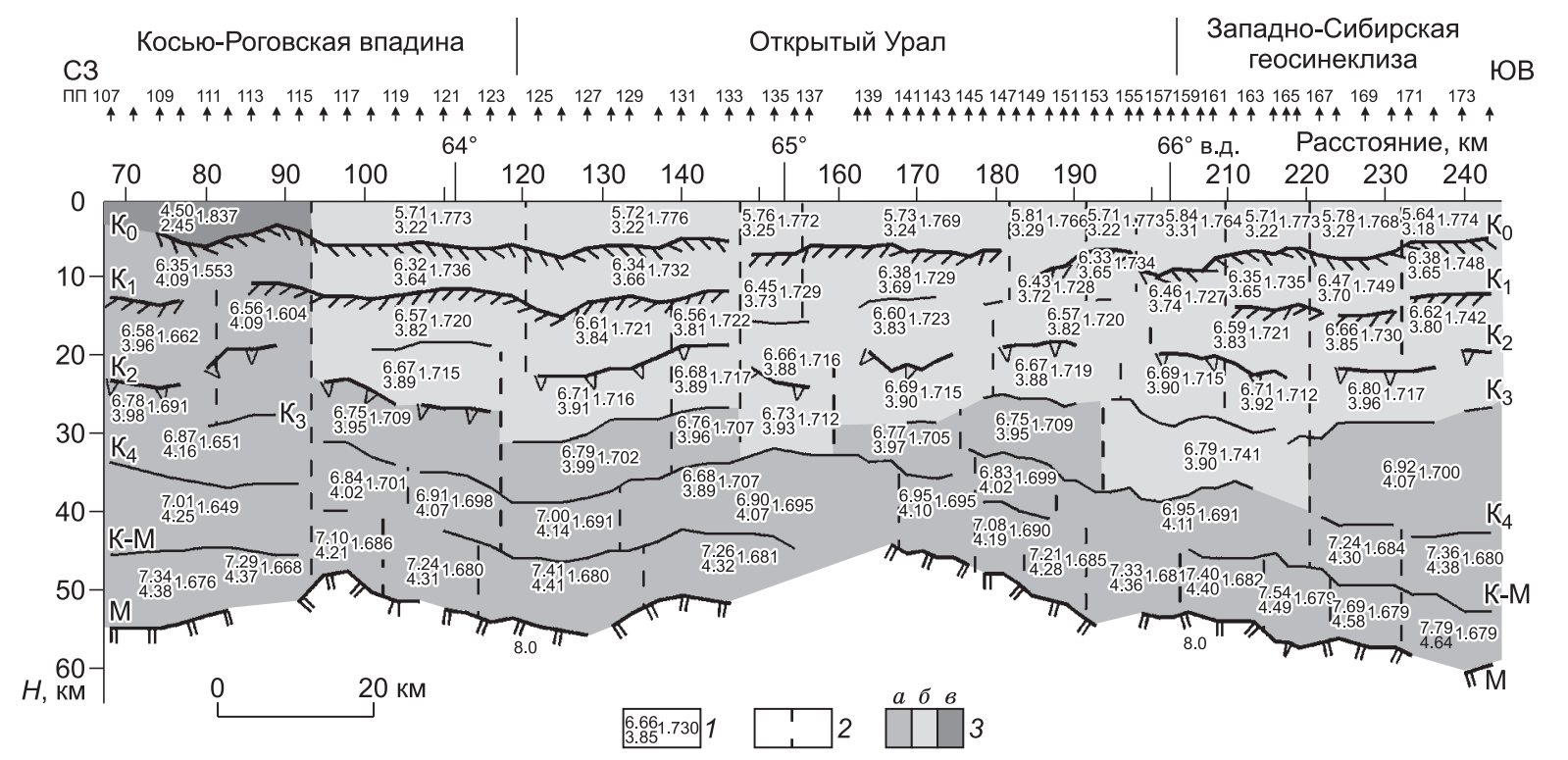

б

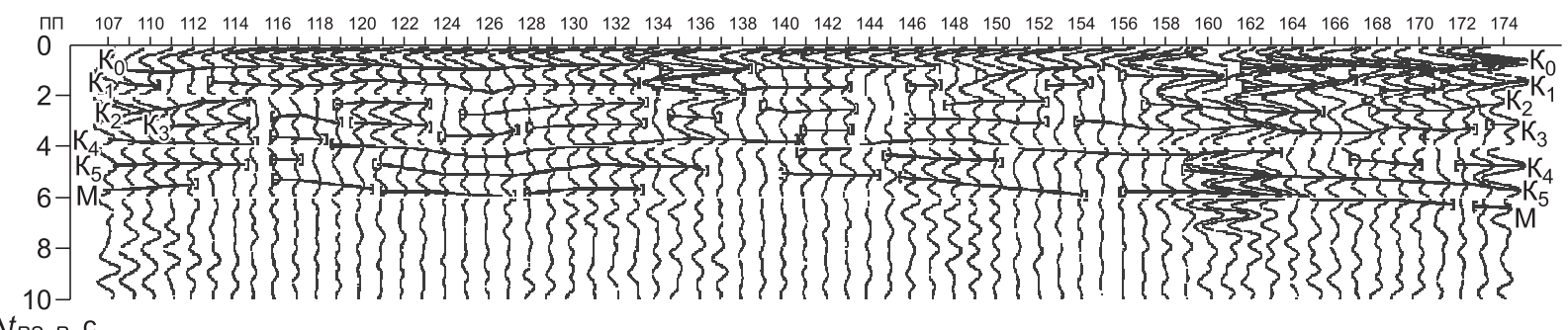

$\Delta t_{P S-P}, \mathrm{c}$

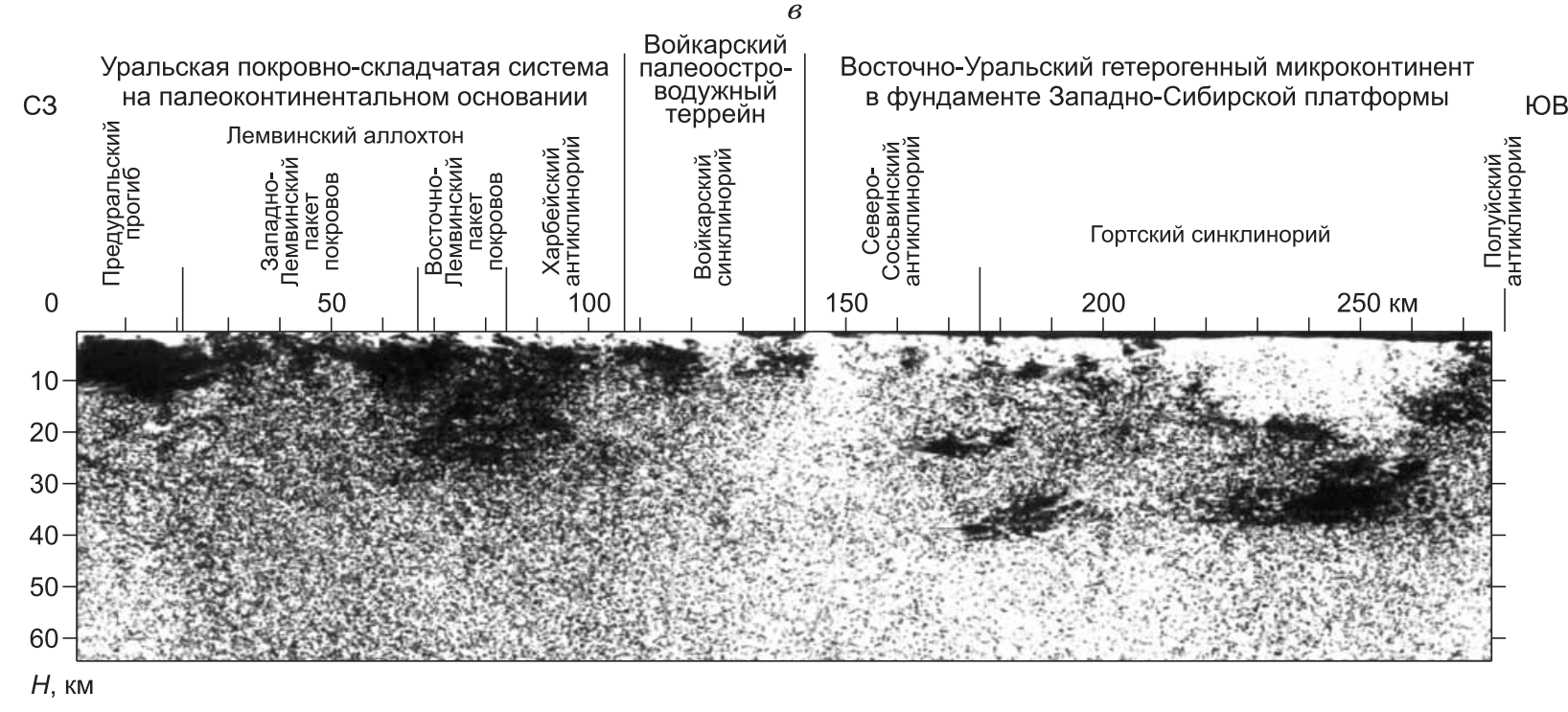

Рис. 3. Сейсмические разрезы по профилю Полярно-Уральский трансект по данным ГСЗ (a), МОВ3 (б) [Золотов и др., 2008], МОГТ (в) [Костюченко и др., 2012].

1 - скорости продольных, поперечных волн $\left(\right.$ км/с) и их отношение; 2 - границы блоков; 3 - градации коэффициента $K\left(v_{P} / v_{S}\right)$ : существенно заниженные значения $K \leq 1.71(a)$, средние $K=1.72-1.78$ (б), повышенные $K \geq 1.79$ (в). Остальные усл. обозн. см. на рис. 2. $a-$ в авторский вариант разреза [Золотов и др., 2008] внесены изменения в название структур в соответствии с расположением осадочных бассейнов; цифровые обозначения границ отмечены, как в работе [Дружинин и др., 2012]. 

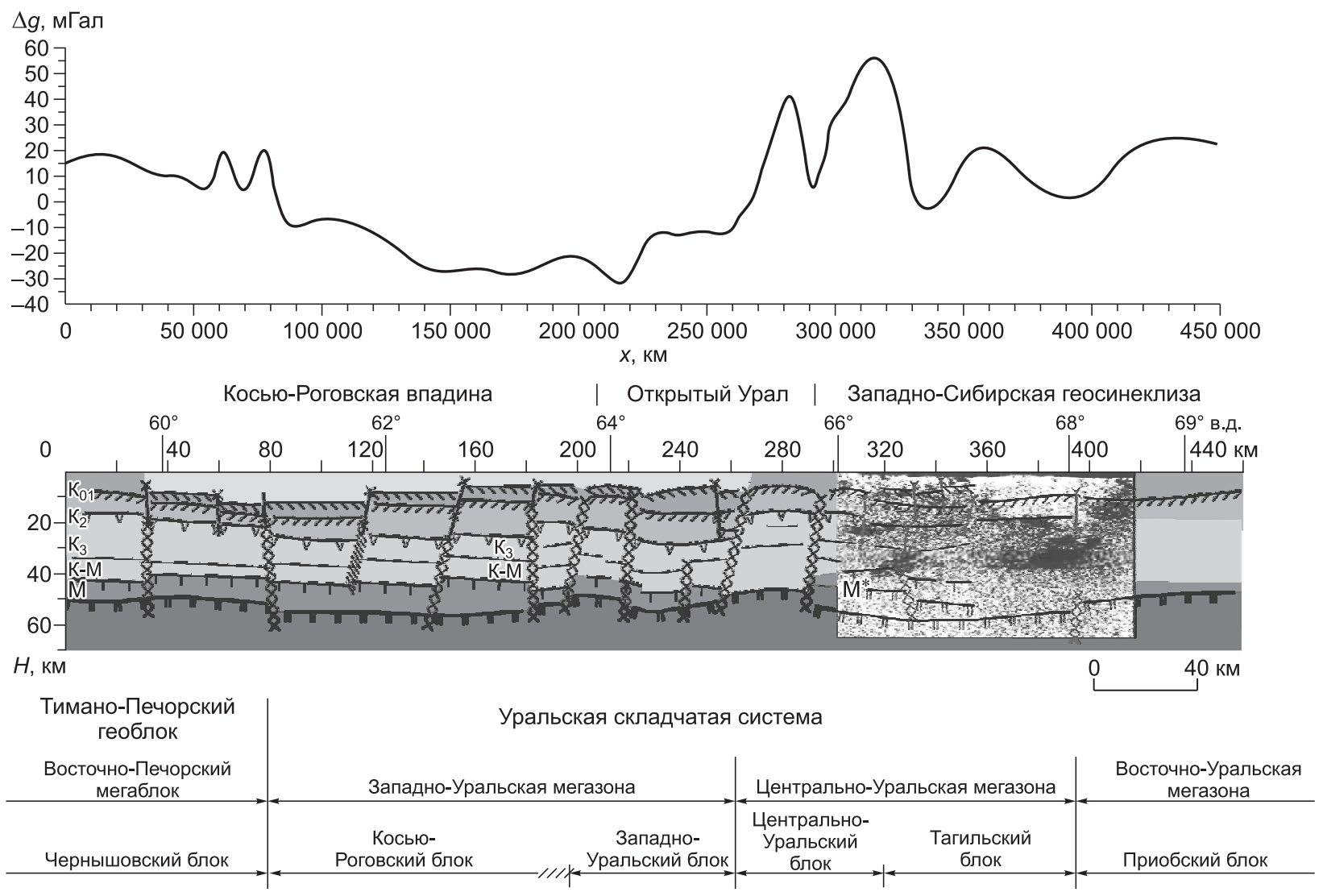

Рис. 4. Сводный субширотный сейсмогеологический разрез земной коры Полярного сектора Уральской складчатой системы.

Над разрезом показана кривая наблюденного гравитационного поля $\Delta g$, а также элементы тектонического районирования УСС с учетом специфики глубинного строения. Усл. обозн. см. на рис. 2.

трясений (МОВ3). Полевые работы выполнены Центром «Геон» в 2007 г. на интервале 175 км. Было зарегистрировано 70 сейсмических событий. В обработку, осуществленную В.В. Недядько, вошло более 1500 сейсмозаписей, полученных по системе точечного зондирования в полосе частот $0.3-15.0$ Гц. Применялась стандартная технология интерпретации, принятая в Центре «Геон». Сравнение глубинного разреза земной коры по системе ГСЗ и временного разреза по МОВЗ подчеркивает их подобие в общих чертах.

Для построения сводного разреза были составлены схемы рельефа по основным поверхностям раздела (древний нижнеархейский кристаллический фундамент $\left(\mathrm{K}_{01}\right)$, нижняя кора $\left(\mathrm{K}_{2}\right)$, основной сейсмогеологический раздел $\mathrm{M}$ между земной корой и комплексами верхней мантии. Помимо профилей ГСЗ использовалась ранее составленная схема тектонического районирования [Дружинин и др., 2009, 2012]. На сводном сейсмогеологическом разрезе (рис. 4), положение которого приведено на рис. 1, имеющиеся данные ГСЗ увязаны таким образом - помимо основных поверхностей раздела $\mathrm{K}_{01}, \mathrm{~K}_{2}$, М показано положение промежуточных границ в земной коре, включая поверхность переходного мегакомплекса КМ. Разрез м-ба 1:1 000000 составлен в рамках разломно-слоисто-блоковой как наиболее вероятной модели глубинного строения.

На рис. 3, в показан глубинный сейсмический разрез МОГТ, составленный А.В. Рыбалка, Т.В. Кашубиной и другими, приведенный в работе [Костюченко и др., 2012]. Разрез представлен разрозненными скоплениями отражающих элементов с достаточно четким разделением его на две части, граница между которыми приходится на зону контакта открытого Урала с Западно-Сибирской геосинеклизой. Намечается разделение частей на более мелкие подразделения, что, вероятно, подчеркивает блоковую модель исследуемой среды. На сводном разрезе приведена информация по ОГТ по восточной части Полярно-Уральского трансекта. Скопление отражающих элементов на уровне 20 и 35-40 км в целом совпадет с сейсмогеологическими поверхностями раздела земной коры $\mathrm{K}_{2}$ и К-М. Разрез по западной части ОГТ не представителен, поэтому на сводном разрезе не показан. 


\section{РЕЗУЛЬТАТЫ}

По особенностям глубинного строения в пределах Уральской складчатой системы в ЗападноУральской мегазоне выделены два блока: Косью-Роговский, соответствующий Предуральскому прогибу, и Западно-Уральский, отвечающий аналогичной по названию зоне складчатости. Центрально-Уральской мегазоне соответствуют два блока: из них западный тождественен поднятию под аналогичным названием, восточный - Тагильскому прогибу. К востоку от $68^{\circ}$ в.д. находится Приобский блок ВосточноУральской мегазоны. Рельеф основных поверхностей раздела изменяется в широких пределах по М от 46 до 60 км, нижней коры от 16 до 28 км, древнего кристаллического фундамента от 7 до 17 км. Мощность второго сейсмогеологического этажа (СГЭ), заключенного между поверхностями раздела $\mathrm{K}_{01}$ и $\mathrm{K}_{2}$, составляет в отрицательных структурах 5-8 км, на поднятиях древнего кристаллического фундамента увеличена до 12-13 км. Мощность нижней коры (третий СГЭ), включая переходный мегакомплекс в ее подошве, существенно больше и изменяется от 23 до 36 км. Нижняя кора расслоена на несколько мегакомплексов, включая указанную выше переходную толщу (поверхность К-М). Блоки разграничены глубинными крутопадающими разломами. Кроме того, к ним приурочена смена скоростных параметров разреза, как это установлено по Полярно-Уральскому трансекту (см. рис. $3, a$ ).

Западнее УСС находится Чернышовский блок поднятий земной коры, относящийся к пограничной структуре Тимано-Печорского геоблока. Аналогичная ситуация характерна для всех более южных пересечений Урала [Дружинин и др., 2013]. Поэтому данный вариант тектонического районирования более предпочтителен, чем ранее нами предлагаемый, который не совпадал с геологическими представлениями о Косью-Роговской впадине как возможного аналога Предуральского прогиба. При этом горизонтальные размеры Западно-Уральской мегазоны увеличены в сечении сводного разреза до 180200 км. Подобный факт обусловлен присутствием в интервале $66-68^{\circ}$ с.ш. своеобразного «кармана» за счет возможных сдвигов блоков Западно-Уральской мегазоны в противоположных направлениях: на юге рассматриваемой территории в северо-восточном со сменой на $67^{\circ}$ с.ш. на северо-западное [Дружинин и др., 2013].

Интересным является вопрос о положении структурных подразделений под мезокайнозойским чехлом ЗСП восточнее $66^{\circ}$ в.д., совпадающей в рассматриваемом сечении с западной границей Тагильского блока. Подобие характеристик глубинного строения в данном сечении и более южных секторах УСС указывает на изменчивое положение структур открытого Урала (неоуралид [Пучков, 2010]) и относительно контуров основных структур восточной части. Эта граница Неоурала по мере продвижения на юг перемещается на более восточные структуры УСС, совпадая в южном секторе с западной границей Тюменско-Кустанайского прогиба (рис. 5). По данным ГСЗ, он относится к пограничной структуре собственно уралид [Дружинин и др., 2013]. Такое положение западной границы осадочного бассейна обусловлено, вероятно, особенностями активизации геодинамических процессов в Западно-Сибирском геоблоке в позднем палеозое и в последующие периоды развития.

Весьма показательной является информация об упругих параметрах, полученная на ПолярноУральском трансекте (ПУТ) (см. рис. $3, a$ ). На фоне в целом пониженных значений коэффициента $K=v_{P} / v_{S}$, равных $1.71 \pm 0.06$, наблюдается существенная аномалия для нижней коры по сравнению с другими пересечениями Урала, где проводились многоволновые исследования. Пониженные значе-

Рис. 5. Соотношение Неоурала [Пучков, 2010] с глубинными структурами кристаллической коры [Дружинин и др., 2013].

1 - граница неотектонических структур [Пучков, 2010]; 2 контуры Уральской складчатой системы, согласно схемы тектонического районирования кристаллической коры [Дружинин и др., 2013]; 3 - положение Центрально-Уральской мегазоны; 4 - пограничный шов по восточной окраине УСС.

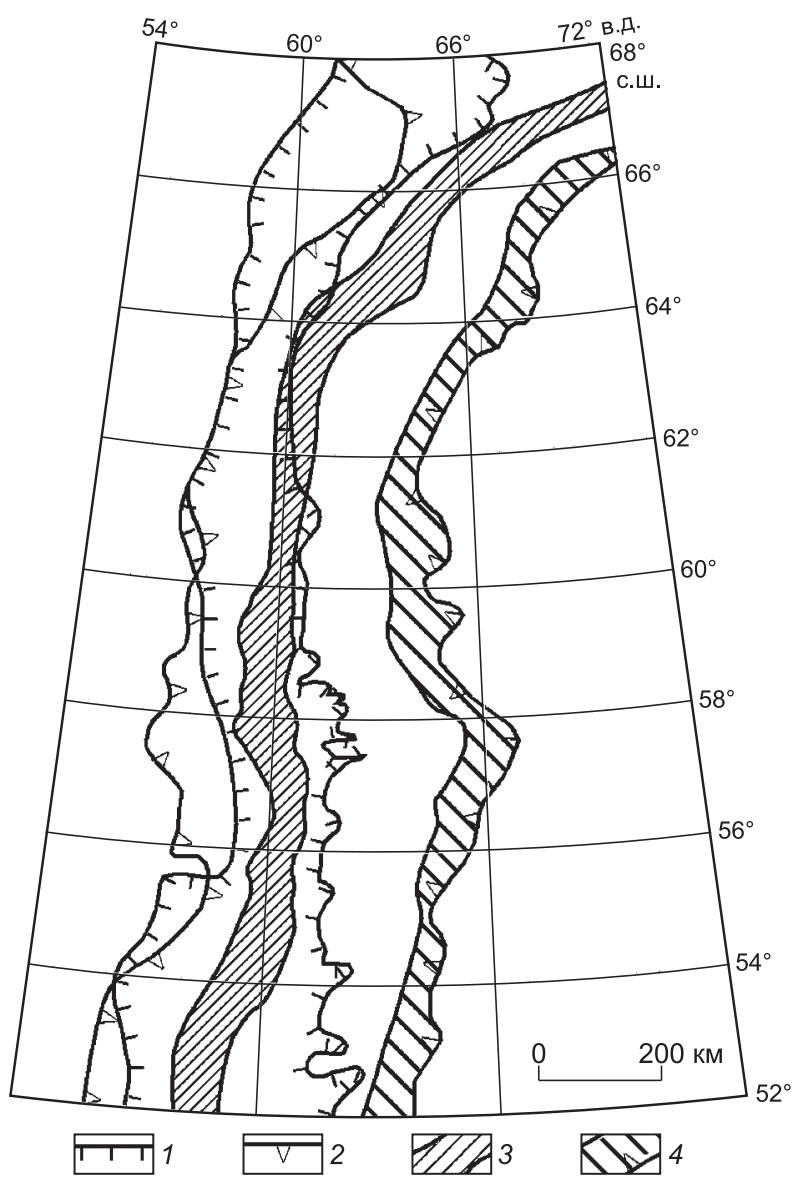


ния коэффициента $K$ не соответствуют предполагаемому основному составу пород этой части разреза. Подобные аномалии для сравнительно небольших горизонтальных блоков (50-70 км) наблюдались на Троицком профиле и международном трансекте Урсейс [Глубинное строение..., 2001]. Были предприняты попытки объяснить это явление процессами гранитизации. Это соответствовало наблюдаемыми над этими блоками отрицательными аномалиями гравитационного поля, указывающими на присутствие ограниченного по глубине гранитоидного массива. Но в случае ПУТ такая гипотеза не проходит по следующим признакам: широкий интервал указанной аномалии (охватывает практически весь профиль) и отсутствие явно выраженных отрицательных аномалий $\Delta g$. Возможной причиной рассматриваемого эффекта является расположение трансекта в субширотной зоне глубинных дислокаций, которая сопровождается пространственно ориентированной микротрещиноватостью и, соответственно, аномалиями значений скорости продольных (уменьшение) и поперечных (увеличение) волн.

Сложная картина глубинного разреза ОГТ, возможно, также обусловлена повышенной раздробленностью коры. Различие волновых картин, наблюдаемых на разных удалениях от источника упругих колебаний: непосредственно вблизи источника в методе ОГТ и на значительных удалениях от него в технологии ГСЗ, вероятно, также обусловлено присутствием в зоне геотраверса субширотной дислокации. Аналогичное явление отмечено на трансекте Урсейс и других пересечениях Центрально-Уральской мегазоны для переходного сложноустроенного мегакомплекса К-М. Как правило, достаточно отчетливая запись отраженных волн на ближних удалениях от источника упругих колебаний зарегистрирована от ее поверхности, а поверхность основного сейсмогеологического раздела М выделена только по преломленным и закритическим отраженным волнам, зарегистрированным на значительном удалении от источника. Но подобная картина установлена для всех глубинных структур Полярного сектора УСС, попадающих в полосу субширотной дислокации. На Полярно-Уральском трансекте в отличие от ОГТ получен достаточно полноценный разрез ГСЗ и МОВЗ. Тем самым еще раз подтверждена эффективность многоволновой сейсмики с использованием волн разного класса, зарегистрированных в широком диапазоне расстояний от источника упругих колебаний, необходимых для изучения земной коры и поверхности

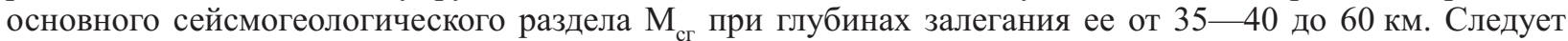
заметить, что для решения региональных задач применимо дискретное профилирование по достаточно полным системам наблюдений с расстояниями межу регистраторами (приемниками) от 2 до 5 км и источниками упругих колебаний $25-50$ км. Вопрос о применении технологии профильного ОГТ для этих целей неясен и требует специального рассмотрения в отношении возможности и необходимости воссоздания детального разреза в условиях сложной трехмерной модели консолидированной коры и с учетом экономической целесообразности подобных исследований. Особенно это относится к районам, где проведение глубинного ОГТ на данный момент невозможно, прежде всего, по орогидрографическим условиям местности. К этому следует добавить, что пока отсутствуют факты, подтверждающие правомерность разрезов ОГТ сверхглубоким и глубоким бурением [Дружинин и др., 2013]. Модель земной коры с несколькими глубинными листрическими разломами [Костюченко и др., 2012, см. рис. 4.29] не соответствует глубинному разрезу ОГТ.

Основные элементы составленной разломно-блоковой модели земной коры совпадают с положением геологических структур и разломов, показанных на тектонической карте, составленной под редакцией Т.Н. Спижарского [1979], выкопировка из которой (в упрощенном виде) приведена на рис. 1. Это может свидетельствовать о наличии прямой связи приповерхностных структур с особенностями глубинного строения. При этом необходимо иметь в виду, что изучается современная модель земной коры, а не время заложения структур первого порядка и динамика их формирования. По мнению авторов, предпочтительнее модель сдвиговой тектоники, в которой реализуются вертикальные и горизонтальные перемещения по субвертикальным глубинным разломам [Дружинин и др., 2013].

Важное значение для региональной геологии имеет решение вопроса о продолжении собственно уралид к востоку от исследуемых районов. Не исключено, что восточнее $72^{\circ}$ в.д. пограничная структура сменяется зоной глубинных дислокаций восток-северо-восточного направления, которая отделяет Заполярный сектор от остальной территории Западно-Сибирского осадочного бассейна. Помимо характерных особенностей потенциальных полей на это указывают результаты бурения Ень-Яхинской сверхглубокой скв. СГ-7, расположенной в 170 км северо-северо-западнее тюменской скв. СГ-6. В нижней части разреза в интервале глубин 6820 - 8250 м обнаружена достаточно мощная толща базальтов триаса явно мантийной принадлежности [Бочкарев, Брехунцов, 2008]. Район скв. СГ-7, возможно, приходится на пересечение Уренгойского субмеридионального поднятия с предполагаемой субширотной дислокацией.

\section{ВЫВОДЫ И ЗАКЛЮЧЕНИЕ}

Положение основных восточных структур УСС (Центрально-Уральская и Восточно-Уральская мегазоны) в Полярном секторе установлено значительно восточнее (до 200 км) по отношению к преобладающему субмеридиональному их направлению в более южных широтах, и оно приурочено к глубинной 
субширотной зоне дислокации. Впервые получено подтверждение наличия мантийного трога (увеличение мощности земной коры до 55-60 км за счет переходного мегакомплекса К-М) на северо-востоке Западно-Сибирской геосинеклизы в пределах 66-68 в.д., характерного для Тагильского прогиба. Не исключено присутствие зоны субширотной дислокации также восточнее $72^{\circ}$ в.д., где она может быть пограничной структурой между Заполярным сегментом и основными структурами Западно-Сибирского геоблока. Установлено уменьшение значений коэффициента $K=v_{P} / v_{S}$, особенно в западной части Полярно-Уральского трансекта для нижней коры. Оно, возможно, обусловлено уменьшением значений скорости продольных волн $\left(v_{P}\right)$ и наоборот, увеличением скорости поперечных волн $\left(v_{S}\right)$. Согласно ранее полученным данным, ПУТ находится в пределах субширотной зоны глубинных дислокаций, направленная микротрещиноватость которой может привести к указанной аномалии скоростных параметров.

В заключение следует подчеркнуть необходимость расширения подобных исследований по изучению строения земной коры Полярного сектора Уральского региона, направленных на создание объемной геолого-геофизической модели земной коры и, соответственно, схемы тектонического районирования в полосе 66-70ㄷ‥, включая южные части Печорского и Карского морей.

Работа выполнена при поддержке УрО РАН (проекты 12-И-5-2067, 12-Т-5-1018 конкурсных программ фундаментальных исследований).

\section{ЛИТЕРАТУРА}

Бочкарев В.В., Брехунцов А.М. Генеральные тектонические модели Западно-Сибирской геосинеклизы // Горные ведомости, 2008, № 3, с. 6-23.

Глубинное строение и геодинамика Южного Урала. Проект Урсейс / Ред. А.Ф. Морозов. Тверь, Изд-во «ГЕРС», 2001, 286 с.

Дружинин В.С., Соболев И.Д., Рыбалка В.М. Связь тектоники и магматизма с глубинным строением Среднего Урала по данным ГСЗ. М., Недра, 1976, 157 с.

Дружинин В.С., Егоркин А.В., Кашубин С.Н. Новые данные о глубинной структуре Урала и прилегающих к нему областей по данным ГСЗ // Докл. АН СССР, т. 315, 1990, № 5, с. 1089-1090.

Дружинин В.С., Колмогорова В.В., Начапкин Н.И., Осипов В.Ю., Брехунцов А.М., Нестеров И.И., Плесовских И.А. Карта доюрских вещественных комплексов северо-западной части Западно-Сибирской равнины на основе объемной модели земной коры // Отечественная геология, 2009, № 1, с. $104-112$.

Дружинин В.С., Мартышко П.С., Начапкин Н.И., Осипов В.Ю., Федорова Н.В. Оценка нефтегазоперспективности Тимано-Печорской плиты с учетом объемной модели верхней части литосферы // Отечественная геология, 2011, № 3, с. 22-29.

Дружинин В.С., Начапкин Н.И., Осипов В.Ю. Роль информации о строении верхней части литосферы Уральского региона для решения региональных задач тектонического районирования и оценки нефтегазоперспективности исследуемых территорий. Германия, LAP LAMBERT Academic Publishing, $2012,153 \mathrm{c}$.

Дружинин В.С., Мартышко П.С., Начапкин Н.И., Осипов В.Ю. Схема тектонического районирования Уральского региона на основе геолого-геофизической информации о строении верхней части литосферы // Отечественная геология, 2013, № 1, с. 43-58.

Егоркин А.В. Строение земной коры по сейсмическим геотраверсам // Глубинное строение территории СССР. М., Наука, 1991, с. 67-95.

Золотов Е.Е., Недядько В.В., Чернышев Ю.А., Гречишников Г.А., Егоркин А.В., Ломова Г.А., Пономарев С.В., Ракитов В.А., Рыжкова И.А. Строение консолидированной коры и верхней мантии вдоль Полярно-Уральского трансекта // Тезисы докладов Десятых геофизических чтений им. В.В. Федынского. М., Центр «Геон», 2008, с. 20-21.

Костюченко С.Л., Морозов А.Ф., Кременецкий А.А. Тимано-Урало-Пайхойская коллизионная область. М., Геокарт-Геос, 2012, 210 с.

Пучков В.Н. Геология Урала и Приуралья (актуальные вопросы стратиграфии, тектоники, геодинамики и металлогении). Уфа, Полиграфсервис, 2010, 280 с. 1979.

Тектоническая карта территории СССР м-ба 10000000 / Ред. Т.Н. Спижарский. СПб., ВСЕГЕИ,

Druzhinin V.S., Kashubin S.N., Kashubina T.V., Kolmogorova V.V., Parygin G.I., Rybalka A.V., Tiunova A.M. The main features of the interface between the crust and the upper mantle in the Middle Urals (in the vicinity of the deep drillhole SG-4) // Tectonophysics, 1997, v. 269, p. 259-267.

Ryzhiy B.P., Druzhinin V.S., Yunusov F.F., Ananyin I.V. Deep structure of the region and its seismicity // Phys. Earth Planet. Inter., 1992, v. 75, p. 185-191. 